Article

\title{
Coupled Relationship between Rural Livelihoods and the Environment at a Village Scale: A Case Study in the Mongolian Plateau
}

\author{
Zhilong $\mathrm{Wu}^{1}{ }^{1} \mathrm{Bo} \mathrm{Li}^{2, *}$, Xuhuan $\mathrm{Dai}^{2}$ and Ying Hou ${ }^{3}$ \\ 1 Institute of Ecological Civilization, Jiangxi University of Finance and Economics, Nanchang 330013, China; \\ wuzhilong@jxufe.edu.cn \\ 2 School of Natural Resources, Faculty of Geographical Science, Beijing Normal University, Beijing 100875, \\ China; daixuhuan@mail.bnu.edu.cn \\ 3 State Key Laboratory of Urban and Regional Ecology, Research Center for Eco-Environmental Sciences, \\ Chinese Academy of Sciences, Beijing 100085, China; yinghou@rcees.ac.cn \\ * Correspondence: libo@bnu.edu.cn; Tel.: +86-13671047495
}

Received: 23 December 2019; Accepted: 29 January 2020; Published: 31 January 2020

\begin{abstract}
Rural livelihoods, which are basic human activities, have long interacted with the environment. In light of the complexity of the human-environment system, more interdisciplinary analyses from geographical, environmental, and social sciences are needed. Using qualitative and quantitative methods from social, environmental, and geographical sciences, this study conducted a geographical regionalization and a comparative analysis of rural livelihoods in different zones in the Loess Plateau to explore the relationship between rural livelihoods and the environment. The results indicated that rural livelihoods are tightly coupled with the environment on a village scale, showing significant geographical regularity and spatial disparity. A combination of geographical location, resource endowment, and environmental sanitation affects rural livelihoods in terms of spatial patterns, development capacity, and quality of life in the context of the public ownership system, the utilization policy of land resources, and limited technical conditions. Coupling the relationship between rural livelihoods and a given environment on a village scale tends to lead to one of four types of relationships: "homeostatic", "intense", "transferred", or "optimized". Accordingly, governments and policymakers need to consider that countryside revitalization must be locally tailored and implemented through the four aspects of "rights revitalization", "labor revitalization", "industrial revitalization", and "environmental revitalization".
\end{abstract}

Keywords: livelihood diversity; environment; village scale; coupling mechanism; farm-pastoral zone

\section{Introduction}

The relationship between humans and the environment has long been discussed, and geographers have successively put forward theories of environmental determinism, possibility theory, reconstruction theory, adaptation theory, and coevolution theory [1]. Among these, the co-evolution theory is widely accepted. It reckons that the relationship between humans and the environment has evolved into a coupled complex system in which people and natural components interact with each other and should exist harmoniously [2,3]. Although many studies have examined human-environment interactions [4-7], the coevolution theory is generally understood on a theoretical level [8]. In light of the complexity and internal mechanisms of the human-environment system, more interdisciplinary analyses from geographical, ecological, and social sciences are needed [9-12].

A person's livelihood, a basic human activity, is his/her main means of interacting with the environment. According to the sustainable livelihood analysis (SLA) framework [13], rural livelihoods 
are shaped by a multitude of different forces and factors. Rural households may encounter multiple barriers in the pursuit of sustainable livelihoods. At the household level, there are physical, financial, and human capital shortages that include a lack of equipment, bank deposits, and skills and poor health [14-16]. At the regional level, the barriers are mainly environmental constraints, such as a lack of natural resources, climate change, limited transportation, and isolated locations [17-20]. The livelihood capital of rural households could be supplemented by policy interventions [21,22], while environmental constraints are more complex and have become the primary reason for poverty in most rural areas [17,23-25]. In China, the dominant factor contributing to regional poverty has changed from institutional constraints and policies to variables in the natural environment $[23,26]$. The crux of persistent poverty in rural areas is largely due to harsh natural conditions, poor locations relative to regional hubs, and uneven regional development [24]. To better understand the interplay between these factors, it is important to systematically explore the rural livelihood-environment nexus.

With respect to studies on rural livelihoods and the environment, most researchers have focused on one-sided effects instead of mutual relationships [27-29]. Researchers have concentrated on the correlations between rural livelihoods and the environment [30,31], poverty traps [32,33], and the spatial clustering of poor populations $[34,35]$. However, these studies have mostly been based on a single livelihood indicator (general per capita net income), which is insufficient to capture deeper relationships and might be biased. Other studies have explored the livelihood-environment relationship on a larger scale (from local (county, municipality) and regional (watershed) to global [36-38]), which may be too broad and ambiguous to make policy recommendations. On the contrary, villages serve as homes, where people both live and produce, and they are the basic unit of rural social economic activity. Villages can therefore be utilized as a window into understanding the coupled human-environment system $[39,40]$.

This study contributes to the current literature on human-environment systems with an interdisciplinary analysis of the coupling relationship between rural livelihoods and the environment on a village scale in the Loess Plateau. The study area (Jungar Banner, Inner Mongolia) was located in the farm-pastoral zone of Northern China. In this area, crop cultivation and grassland husbandry have spatially overlapped through time [41,42]. Rural livelihoods have traditionally been dominated by animal husbandry combined with crop cultivation to feed the animals [43]. During the past several decades, due to rapid industrialization and urbanization coupled with environmental deterioration caused by excessive human activities, rural livelihoods have transformed from a traditionally single and fixed farm-pastoral pattern to a more diversified and flexible pattern accompanied by inefficient land use, ecological degradation, empty villages, etc. [44-46]. Therefore, Jungar Banner in Inner Mongolia represented a typical case for rural livelihood-environment nexus research. Using the tools of a household survey from the social sciences and a geographical information system (GIS) from geographical science, this study aimed to (i) determine the environmental heterogeneity of the chosen villages based on geographical regionalization; (ii) identify and characterize rural livelihoods in terms of livelihood strategies and outcomes based on econometric methods; and (iii) explore the internal coupling mechanisms and relationship types between rural livelihoods and the environment. Our study narrows the research gap because few studies have systematically analyzed the rural livelihood-environmental nexus on a village scale combining the sciences of geography and sociology. The relevant results may provide references for China's countryside revitalization and global human-environment relationship management.

\section{Study Area}

Due to its unique geographical location, Jungar Banner possesses the physical geography, culture, economy, and social development of a typical farm-pastoral zone. Jungar Banner lies in the midwestern part of Inner Mongolia, a northern farm-pastoral zone in China that is southeast of the Ordos Plateau (a part of the Loess Plateau), at E110 $05^{\prime}-111^{\circ} 27^{\prime}, \mathrm{N} 39^{\circ} 16^{\prime}-40^{\circ} 20^{\prime}$, lying at the junction of Shanxi Province, Shaanxi Province, and Inner Mongolia (Figure 1). The Banner has a total area of $7692 \mathrm{~km}^{2}$, with hilly 
and gully landforms mainly comprised of chestnut soil, loessal soil, aeolian sandy soil, and alluvial soil. The climate is temperate continental semiarid, with an average annual rainfall of between 379 and $420 \mathrm{~mm}$. The natural vegetation types include thicketization-steppe and typical steppe, and the main crops are corn, broom corn, millet, potato, wheat, and sunflowers. The region's unique physiographic conditions determine the long-term agricultural development characteristics of both farming and husbandry, with goats, sheep, cows, and pigs making up the primary livestock industry. The farming and husbandry industries in Jungar Banner account for about 50.93\% and 40.30\%, respectively, of the total value of the primary industry, reflecting the characteristics of a typical farm-pastoral zone. Meanwhile, as a resource-oriented county with coal reserves estimated to be as large as $5.20 \times 1010 \mathrm{t}$, Jungar possesses a developed coal chemical industry. In 2017, the production value of agriculture, industry, and services accounted for, respectively, 1.1\%, 55.4\%, and 43.5\% of Jungar's GDP [47]. There are nine towns and four subdistricts (including 159 administrative villages and 20 communities) in Jungar Banner, with a multiethnic population of 326,500 at the end of 2017.

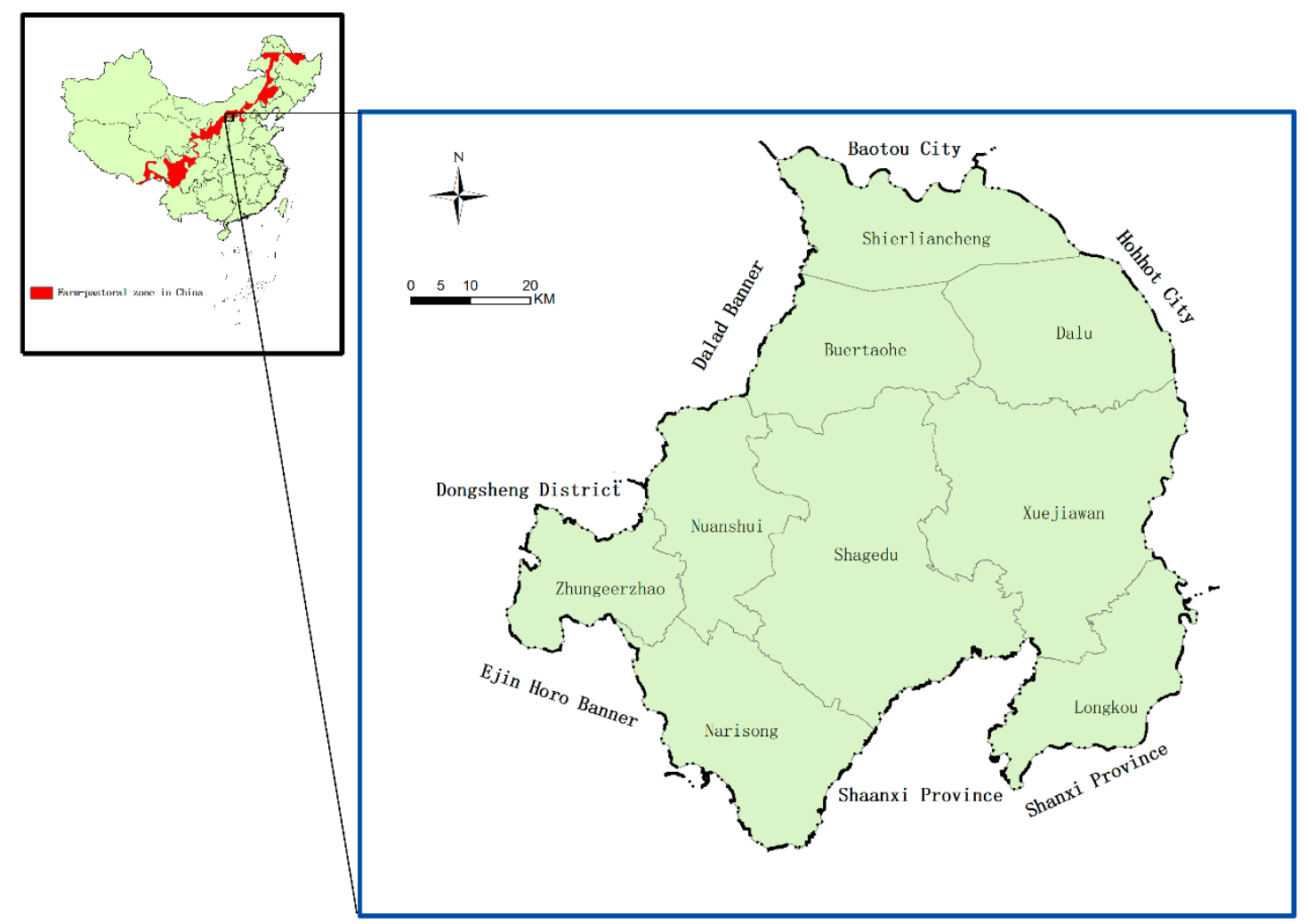

Figure 1. The location of Jungar Banner.

\section{Methodology}

The sustainable livelihoods analysis (SLA) framework proposed by the Department for International Development (DFID) has been widely accepted and applied in many studies. Composed of five parts—vulnerability context, livelihood capital, transformation of structures and institutions, livelihood strategy, and livelihood outcomes-the SLA framework provides a full checklist of issues related to livelihoods. It informed our analysis and data collection in several ways. However, the SLA framework mainly focuses on individual or household livelihoods and does not sufficiently consider the role of the environment in shaping rural livelihoods at a community level. Adopted from the SLA framework, this study constructed a methodological framework for rural livelihood-environmental nexus analyses and employed multiple methods from social, environmental, and geographical sciences (Figure 2). This study was mainly composed of four parts. (i) The construction of a database: A database was composed for two kinds of data, i.e., spatial data and household survey data. The former was 
prepared for geographical regionalization, while the latter was prepared for rural livelihood analyses. (ii) Geographical regionalization: the geographical regionalization was based on a multifactor spatial overlay analysis and expert consultation. (iii) Rural livelihood analysis: Based on the geographical regionalization, typical villages were selected and rural livelihoods were analyzed at a village level. Rural livelihood strategies were classified through qualitative and quantitative methods, while a livelihood diversity index and family net income were quantitatively analyzed and tested through the Kruskal-Wallis method. (iv) Coupling mechanism analysis: On the basis of the previous three sections of work, different types of relationships and the internal coupling mechanisms between rural livelihood and the environment on a village scale were summarized through induction and deduction methods. The approach to studying the human-environment relationship, both on a village and regional scale, was based mainly on econometric methods, e.g., the Kruskal-Wallis H test on an inversed Herfindahl-Hirschman index.

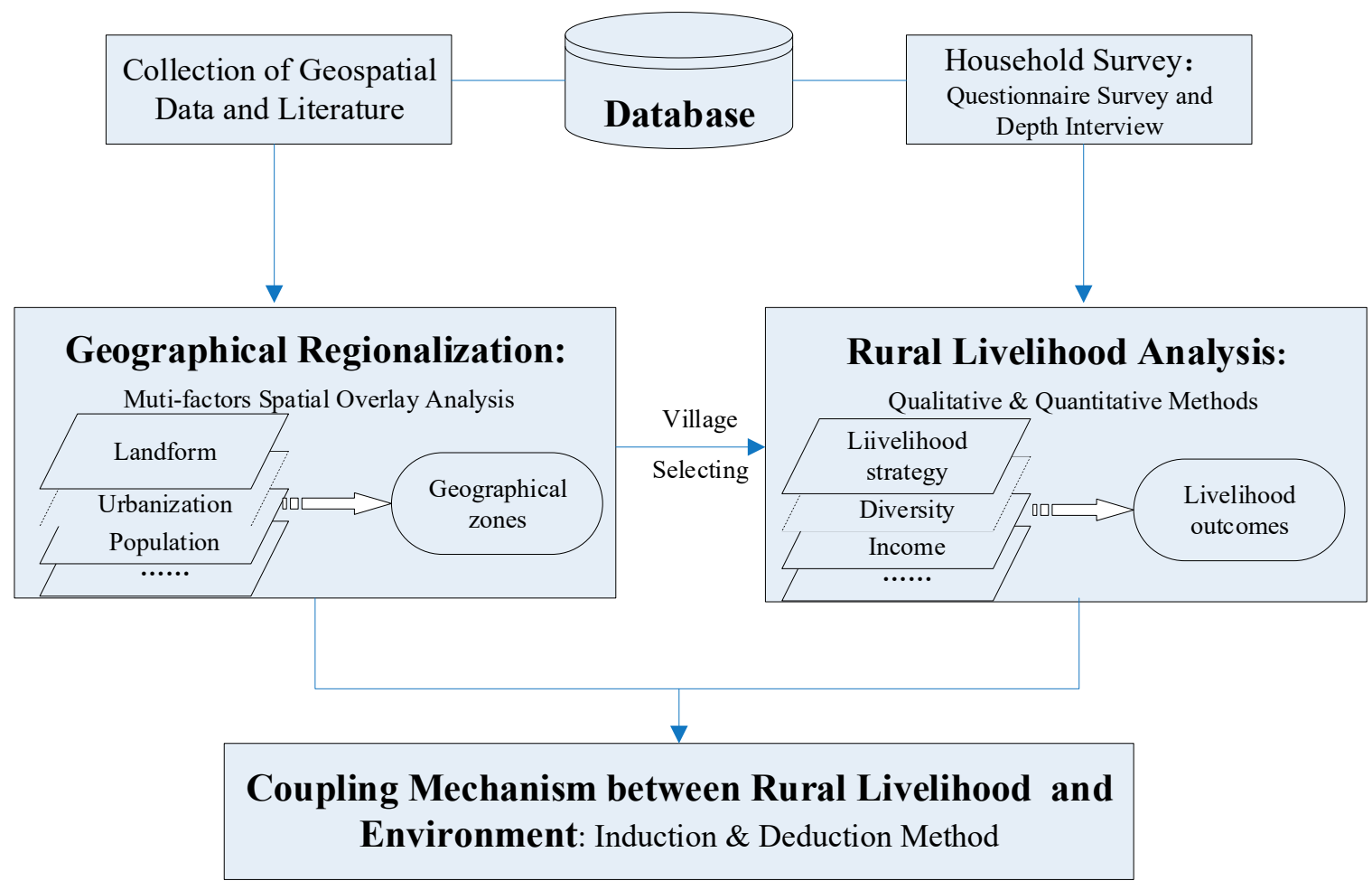

Figure 2. Methodological framework for rural livelihood-environment nexus analysis.

\subsection{Data Collection}

The spatial data mainly concerned multiple environmental elements and were used for geographical regionalization. Landform data were collected from the Geospatial Data Cloud hosted by the Chinese Academy of Sciences; soil type data were gained from the Harmonized World Soil Database; population data were acquired from the Jungar Statistics Bureau; and land use data, hydrology data, mineral resources, and traffic conditions information were obtained from the Jungar Department of Natural Resources. These spatial data were processed in a standard way and stored in the platform of a geographical information system (GIS).

For the household survey, we adopted a participatory rural appraisal method (PRA), which included direct observation, questionnaire surveys, and in-depth interviews. The questionnaire included information on demography, occupation, family income and expenditures, land use, water use, energy use, and the welfare of farmers. In-depth interviews with regional agencies, such as with the village leader and the town mayor, mainly focused on infrastructure investment, the presence of resources and environmental sanitation, and development plans and strategies for villages by local 
governments and organizations at the county, township, and village level. In accordance with the geographical regionalization, we conducted a special investigation in four villages and collected 168 valid questionnaires through random household sampling in December 2015. There were 31 valid samples from 266 households in the village of Wujiayao, 30 valid samples from 551 households in the village of Gongyigai, 44 valid samples from 368 households in the village of Fulu, and 63 valid samples from 584 households in the village of Changtan.

\subsection{Geographical Regionalization}

Comprehensive geographical regionalization is based on rules governing the regional differentiation of physical and human geography factors overlaid on a GIS, such as landforms, soil, hydrology, transportation, minerals, population, urbanization, land use, and land cover. Using regional differences and similarities in geographical factors, this study aimed to divide the study area into relatively independent, complete, and organically linked geographical units. Multiple principles were adopted, such as synthesis, dominant factors, the relative consistency of the natural environment, the relative consistency of economic and social development, the consistency of the regional cultural landscape, the continuity of spatial distribution, and the integrity of village-level administrative divisions. This informed the regionalization in several ways: (i) The comprehensive geographical regionalization integrated multiple elements associated with nature, society, and the economy. (ii) The dominant factors were mainly landforms, resource endowment, urbanization, and population (with weights and priority). We first drew a regionalization draft according to landforms and preliminarily divided the study area into four zones: the alluvial plain south of the Yellow River, the Kubuqi Desert area, the central sandstone hilly-gully area, and the southern loess hilly-gully area. Secondly, we adjusted the draft according to resource endowment, especially coal resources, and marked out mining areas from the central sandstone hilly-gully area and the southern loess hilly-gully area. Then, we separated the concentrated population and urban development zone from the former central sandstone hilly-gully area according to conditions of urbanization and population development. (iii) In order to maintain the integrity of the natural and human landscape, the regionalization draft was modified in line with the boundaries of administrative villages, roads, water areas, mountains, etc.

A method of expert consultation was applied. The experts were mainly scholars from the Institute of Geographic Sciences and Natural Resources Research, Chinese Academy of Sciences (CAS), China Agricultural University, and Beijing Normal University and staff from local government and functional departments, including the Bureau of Agriculture and Rural Affairs, the Jungar Forestry Bureau, and the Department of Natural Resources. Through rigorous discussions with the expert group, the geographical regionalization was finally determined after several rounds of responses and modifications.

\subsection{Rural Livelihood Analysis}

\subsubsection{Classification of Livelihood Strategies}

Livelihood strategies in Jungar Banner were classified and assessed [46]. To consider the farm-pastoral characteristics and the "income composition and vocation" of local farmers, a quantitative and qualitative integrated method was used to categorize strategies into either plantingor stockbreeding-oriented (these two patterns can be referred to as agriculture-oriented), half-labor and half-peasant, nonagriculture-oriented, or subsidized (see Table 1). 
Table 1. Livelihood strategies in Jungar Banner. ${ }^{1}$

\begin{tabular}{|c|c|c|c|c|c|c|}
\hline \multirow{2}{*}{\multicolumn{2}{|c|}{ Dividing Bases }} & \multicolumn{2}{|c|}{ Agriculture Oriented Livelihood } & \multirow{2}{*}{$\begin{array}{c}\text { Half-Labor and } \\
\text { Half-Peasant } \\
\text { Livelihood }\end{array}$} & \multirow{2}{*}{$\begin{array}{c}\text { Nonagriculture- } \\
\text { Oriented } \\
\text { Livelihood }\end{array}$} & \multirow[b]{2}{*}{$\begin{array}{l}\text { Subsidized } \\
\text { Livelihood }\end{array}$} \\
\hline & & $\begin{array}{l}\text { Planting-Oriented } \\
\text { Livelihood }\end{array}$ & $\begin{array}{l}\text { Stockbreeding-Oriented } \\
\text { Livelihood }\end{array}$ & & & \\
\hline $\begin{array}{c}\text { income } \\
\text { composition } \\
\text { (quantitative) }\end{array}$ & $\begin{array}{l}\text { main } \\
\text { indicators }\end{array}$ & $\begin{array}{l}\text { planting income } \\
\text { ratio } \geq 60 \%\end{array}$ & $\begin{array}{l}\text { income ratio of animal } \\
\text { husbandry } \geq 60 \%\end{array}$ & $\begin{array}{c}\text { balanced income } \\
\text { ratio from } \\
\text { agriculture }(\mathrm{A}) \\
\text { and } \\
\text { nonagriculture }(\mathrm{B}): \\
\mathrm{A}+\mathrm{B} \geq 60 \% \text { and } \\
6: 4 \geq \mathrm{A}: \mathrm{B} \geq 4: 6\end{array}$ & $\begin{array}{c}\text { nonagriculture } \\
\text { income ratio } \geq \\
60 \%\end{array}$ & $\begin{array}{c}\text { subsidized } \\
\text { income } \\
\text { ratio } \geq 60 \%\end{array}$ \\
\hline $\begin{array}{l}\text { living means } \\
\text { (qualitative) }\end{array}$ & $\begin{array}{l}\text { complementary } \\
\text { indicators }\end{array}$ & $\begin{array}{l}\text { Planting-oriented } \\
\text { with large } \\
\text { cultivated area or } \\
\text { engaged in facility } \\
\text { agriculture, and } \\
\text { planting } \\
\text { production is } \\
\text { mainly for sale }\end{array}$ & $\begin{array}{l}\text { Stockbreeding-oriented } \\
\text { with lots of animals in } \\
\text { stock, and planting } \\
\text { production is mainly } \\
\text { for self-consumption }\end{array}$ & $\begin{array}{l}\text { doing farm work } \\
\text { in homeland } \\
\text { during farming } \\
\text { season and odd } \\
\text { jobs outside } \\
\text { during slack } \\
\text { seasons }\end{array}$ & $\begin{array}{l}\text { nonagriculture- } \\
\text { oriented with } \\
\text { special skills, or } \\
\text { most time spent } \\
\text { on migrant work }{ }^{3}\end{array}$ & $\begin{array}{l}\text { subsidized } \\
\text { income- } \\
\text { supported } \\
\text { with aged } \\
\text { labor force }\end{array}$ \\
\hline
\end{tabular}

${ }^{1}$ For detailed information about livelihood strategies in Jungar Banner, see Reference [46]. ${ }^{2}$ Subsidized income mainly refers to subsidies from cropland retirement, pension subsidies, ecological compensation, child support, and rural minimal social security subsidies. ${ }^{3}$ Migrant work refers to low-end manual jobs in economically developed areas adopted by migrant farmers from rural China, e.g., cleaning and building work.

\subsubsection{The Livelihood Diversity Index}

A two-dimensional calculation method that considered both the types of livelihood activities and the percent of income from the various livelihood activities was employed to measure livelihood diversity, including the inversed Herfindahl-Hirschman index. The intrinsic meaning of the inversed Herfindahl-Hirschman index is as follows: the more sources of income and the more balanced the proportions of the various incomes a household has, the higher the livelihood diversity index is, and the household has lower livelihood risks and more stable living levels [48]. As has been confirmed by existing empirical studies, the inversed Herfindahl-Hirschman index is in line with the actual situation in rural China and reflects the livelihood status of rural households accurately [14,49]:

$$
H L D I=\frac{1}{\sum_{h=1}^{n} I P_{h}^{2}}
$$

where HLDI is the household livelihood diversity index, $\mathrm{IP}_{\mathrm{h}}$ is the proportion of income activity to total income, and $\mathrm{n}$ is the number of income activities for a specific household. In accordance with rural livelihood characteristics in Jungar Banner, this paper divided livelihood activities into three types: farm activities, nonfarm activities, and subsidized activities. Farm activities were subdivided into planting activities (including planting food crops, cash crops, seedlings, seeds, and other things) and animal husbandry activities (including the production of meat, milk, and fur). Nonfarm activities were subdivided into skilled employment and unskilled employment. Skilled employment refers to fixed and stable work that requires higher education, special skills, and good health, such as jobs in the service industry, urban construction, and manufacturing. Unskilled employment refers to temporary short-term work or low-level, easy-to-replace work, such as harvesting, the construction of agricultural infrastructure, and the work of cleaners and porters. Subsidized activities include participation in farmland retirement, ecological immigration, endowment insurance, land expropriation, and being listed as a low-income household. These activities are for public welfare purposes and are compensated or subsidized by the government or its agents. Correspondingly, livelihood incomes were divided into five categories: planting income, animal husbandry income, skilled employment income, unskilled employment income, and subsidized income. The five categories covered almost all of the income activities of farm households in Jungar Banner. The livelihood diversity index ranged from 1 to 5 , with the highest index value (indicating the best situation) meaning that rural households had five balanced income sources, while the lowest index value (indicating the worst situation) meant that rural households depended only on one income source. 


\subsubsection{Kruskal-Wallis H Test}

The Kruskal-Wallis $\mathrm{H}$ test is a nonparametric method for checking multiple sets of scores that come from different groups to verify whether there are significant differences in the distribution of multiple populations. It is nonparametric and equivalent to a one-way ANOVA (analysis of variance). The hypothesis was that there is no significant difference in the distribution of multiple independent samples from multiple populations. Here, the Kruskal-Wallis $\mathrm{H}$ test was used to examine the regional diversity of rural livelihood outcomes (livelihood diversity index, family net income) among the four sampled villages. If the test statistic was in the critical region, the null hypothesis that rural livelihood outcomes in different villages were approximately the same was rejected.

The main procedures were as follows: (i) rank all of the data of a specific index from all of the groups; (ii) calculate the Kruskal-Wallis H-test statistic:

$$
H=\frac{12}{n_{T}\left(n_{T}+1\right)} \sum_{i} \frac{T_{i}^{2}}{n_{i}}-3\left(n_{T}+1\right),
$$

where $n_{T}$ is the total observations of a specific index (e.g., livelihood diversity index, family net income) across all groups; $T_{i}$ is the sum of the ranks for group $i$; and $n_{i}(i=1,2, \ldots, \mathrm{k})$ represents the number of observations in group $i$.

\section{Results}

\subsection{Characteristics of Geographical Zones and Typical Villages}

On the basis of geographical and environmental features, including geomorphology, soil, hydrology, population, transportation, and economic location, Jungar Banner can be divided into five zones (classified into four types) from north to south. The four zone types are a modernized farm-pastoral plain along the Yellow River, a traditional farm-pastoral zone of the Kubuqi Desert, a concentrated population and urban development zone, and a loess hilly-gully mining zone (Figure 3). Accordingly, we then selected four typical villages and analyzed their geographical characteristics. There existed sharp socioeconomic disparities between these zones and villages. 


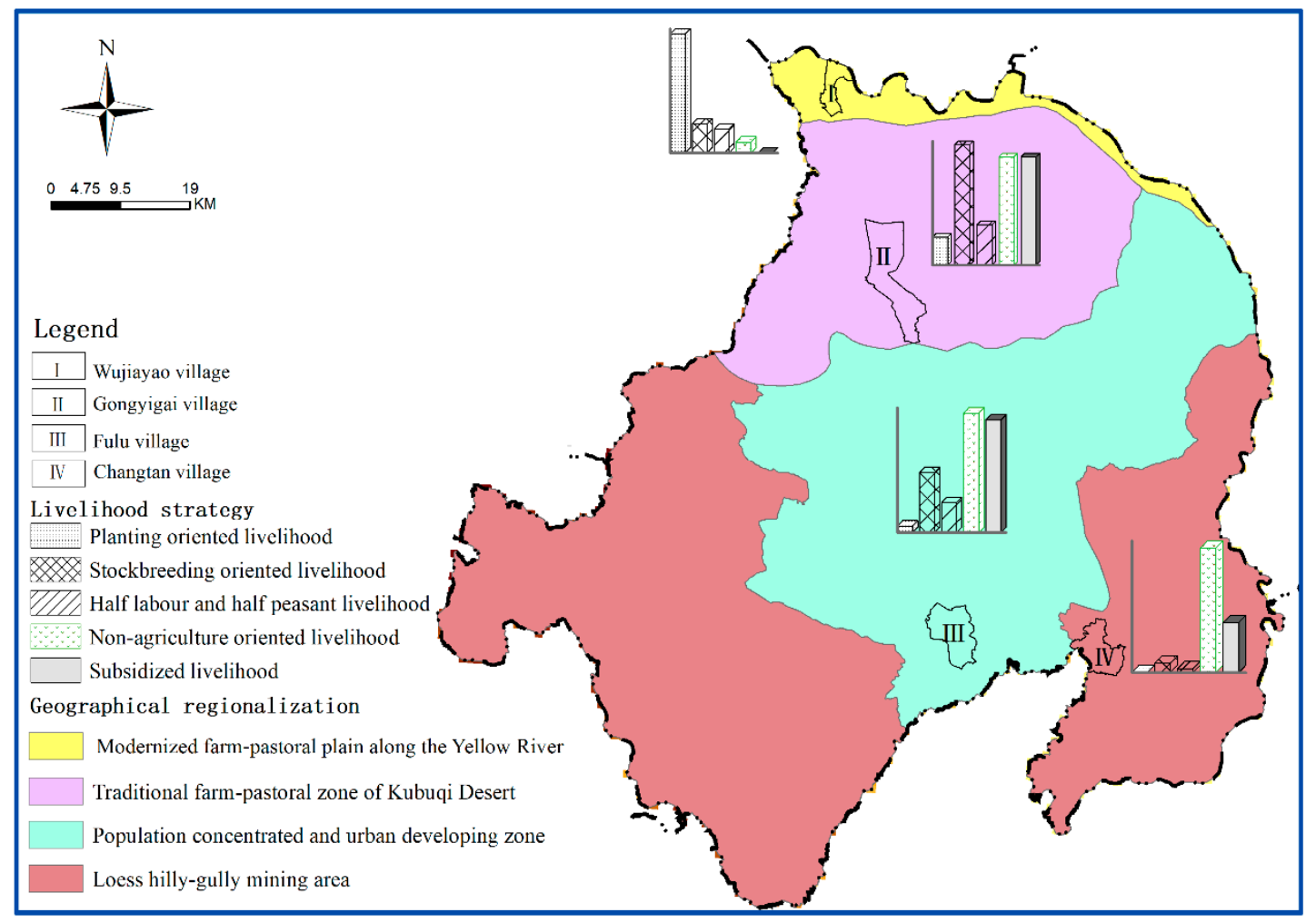

Figure 3. Geographical regionalization and livelihood patterns in Jungar Banner.

\subsubsection{Modernized Farm-Pastoral Plain along the Yellow River and Wujiayao Village}

The alluvial plain is located on the northern edge of the county between the Kubuqi Desert and the Yellow River, mainly covering the northern part of the township of Shierliancheng. It is bordered by the city of Baotou in the north and the city of Hohhot in the east. This zone has a total area of $222.10 \mathrm{~km}^{2}$ and is $8 \mathrm{~km}$ long from north to south and $40 \mathrm{~km}$ long from west to east, accounting for $2.89 \%$ of the whole county. The alluvial plain is comprised of fine sand, moist soil, and a small area of saline soil. It possesses great potential for agriculture due to its flat land, fertile soil, and sufficient water supply. The area has benefited from its location and these prime natural conditions and has developed into both the main grain base of Jungar Banner and the commodity grain production base for the Inner Mongolia Autonomous Region. The base adopts a "company + base + farmers" mode and focuses on agricultural products such as fruits, fresh milk, and seasonal vegetables. It realizes intensive and industrial production from modern agriculture and animal husbandry. The rural settlements are relatively concentrated with relatively high population densities.

The village of Wujiayao is in the plain to the south of the Yellow River, bordering Jikesitai of Dalad Banner in the west and adjacent to Tumoteyou Banner of the city of Baotou in the north across from the Yellow River. It possesses convenient transportation and an obvious advantage in location. The total area of the village is $58.49 \mathrm{~km}^{2}$, with 266 households and a total population of 1027 . The terrain of the village is flat. The soil type is dominated by fluvial -aquic soil, with solonchak distributed over a small area. Generally, the soil is fertile and water resources are sufficient. The village owns $33.83 \mathrm{~km}^{2}$ of cultivated land, which is spatially concentrated and entirely irrigated, with $18.83 \mathrm{~km}^{2}$ of grassland and $4.34 \mathrm{~km}^{2}$ of water area. These characteristics provide great potential for agricultural development in this village (Figure 4). In 2007, Wujiayao was listed as a pilot for a new rural construction project and a demonstration base for modern agriculture and animal husbandry in the Inner Mongolia Autonomous Region, Ordos City, and Jungar Banner. The government has successively invested 29.26 million yuan, and thus basic facilities such as agricultural water conservancy, transportation, and living services are relatively well equipped. With the support of local policies, Wujiayao's development strategy is 
"determining industry by resources, determining employment by industry, determining population by employment, and determining community by population". The village has also introduced an agricultural model of "company + base + farmers". Specifically, an agricultural company rents farmers' land and invests in construction. The industry base, consisting of local government, agricultural companies, and farmers, is responsible for centralized management, production, and sales. The farmers farm on rented land from companies. Under these circumstances, Wujiayao has realized industrial planting and stockbreeding, created standard residential communities, and unified and centralized their management.
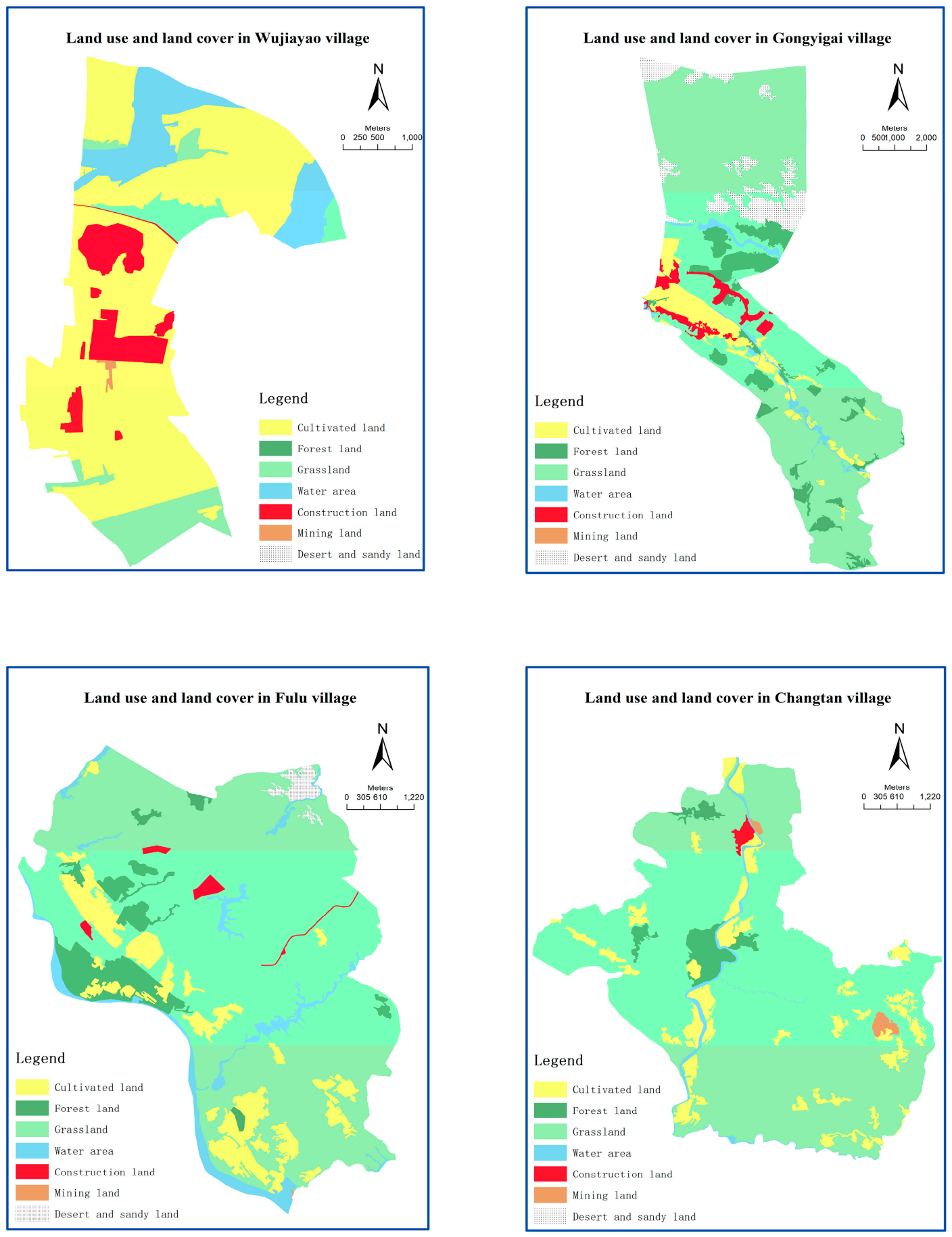

Figure 4. Land use patterns in four villages in 2015 (adopted from the Jungar Department of Natural Resources). 


\subsubsection{The Traditional Farm-Pastoral Zone of Kubuqi Desert and Gongyigai Village}

This area is located in the Kubuqi Desert between the plains to the south of the Yellow River and the central hilly-gully region. It is associated with the townships of Buertaohai and Shierliancheng and has a total area of $1488.95 \mathrm{~km}^{2}$, accounting for $19.36 \%$ of the whole county. This area is covered with flowing, semifixed, and fixed sandy land, and the soil type is dominated by sandy soil. In this zone, a large area of intermontane lowlands with relatively sufficient natural fertility and water constitutes an ideal base for animal husbandry, forestry, and crop cultivation. The state-owned Wulanbulang Forest Farm and the Buertaohai Sand Station are located in this area and have become an environmental defense for the area. However, the overall ecosystem is fragile, lacks water, and is invaded by sand winds frequently. The local population is scattered throughout the area, mainly concentrated in Buertaohai and engaged in traditional crop cultivation and grassland husbandry.

The village of Gongyigai is in the Kubuqi Desert area in the northern part of Jungar Banner. This village has a total area of $263.81 \mathrm{~km}^{2}, 6$ production cooperatives, 551 households, and 1141 people, of whom 473 are permanent residents. Sand winds have frequently invaded this village for many years, resulting in many mobile, semifixed, or fixed sand dunes, with mainly aeolian sandy soil. In light of this, a state-owned forest farm and a sand station were built as ecological protection barriers. In these barrier mountains, there are large areas of lowlands ideal for producing forestry and husbandry products with sufficient water. As shown in Figure 4, the village has $6.28 \mathrm{~km}^{2}$ of cultivated land, including $4.92 \mathrm{~km}^{2}$ of irrigated land and $1.36 \mathrm{~km}^{2}$ of dry land, $9.4 \mathrm{~km}^{2}$ of forest, $229.81 \mathrm{~km}^{2}$ of grasslands, $1.56 \mathrm{~km}^{2}$ of water areas, and $14.95 \mathrm{~km}^{2}$ of sandy land. There are 28 standard sheds for livestock, with an area of $1360 \mathrm{~m}^{2}$, and there are 23 fodder silos holding $520 \mathrm{~m}^{3}$. Considering its resources, environmental conditions, and economic development, Gongyigai is a typical traditional farm-pastoral village in the northern farm-pastoral zone.

\subsubsection{Concentrated Population and Urban Development Zone and Fulu Village}

This zone is at a low elevation and includes a major urbanized area and most of the population. Located in the middle of the county, this zone includes most parts of the township of Shagedu, the township of Dalu, and the northern area of the township of Xuejiawan. Shagedu is the former site of the county government, with a long history and completed public service facilities. Xuejiawan and Dalu are the current sites of county government and various departments, with integrated public services, urban construction, economic development, population support, culture, and education. This zone also possesses large-scale coal chemical companies. Accounting for $32.49 \%$ of the whole county, this zone has a total area of $2499.09 \mathrm{~km}^{2}$. The Nalinchuan River is a main feature, and the soil is mainly chestnut soil, which gives the area the potential for grass planting, livestock breeding, and dry-land farming. However, due to its high population density and long-term disturbances from human activities, such as overgrazing and extensive cultivation, there is widespread severe soil erosion, resulting in densely distributed gullies and exposed bedrock.

The village of Fulu is in the hilly-gully area in the central region of Jungar Banner, adjacent to the urban area of Shagedu (where the former Jungar Banner government was located), and it spreads from the northwest to the southeast along the Huangpuchuan River. The village has a total area of $66.73 \mathrm{~km}^{2}$ and a permanent population of 368 households with 1115 people. The northeastern part of the village has high terrain where hills and valleys are densely distributed. Most of the settlements and cultivated lands are in the southwest with low and flat terrain. There are two reservoirs located within the village; however, water storage is insufficient, with only $10.35 \mathrm{~km}^{2}$ of water. The soil type is dominated by chestnut soil. The village has $3.76 \mathrm{~km}^{2}$ of cultivated land, $48.92 \mathrm{~km}^{2} 2$ of grasslands, $2.44 \mathrm{~km}^{2}$ of forest, and $0.42 \mathrm{~km}^{2}$ of sandy land (Figure 4). Due to its suburban location and a lack of scientific planning and management, farmers' residential sites in Fulu are scattered and suffer from poor environmental sanitation caused by domestic garbage. In addition, a lack of planning in terms of historical land use has resulted in overgrazing, extensive cultivation, and a high population density, further causing serious soil erosion. 


\subsubsection{Loess Hilly-Gully Mining Area and Changtan Village}

This area can be divided into two parts. The southwestern hilly-gully coal mining area includes the townships of Zhungeerzhao, Nuanshui, and Narisong, covering an area of $2277.99 \mathrm{~km}^{2}$ and accounting for $29.62 \%$ of the whole county. This area has a high elevation, hilly landforms, rolling mountains and valleys, and densely populated valleys. The soil type is dominated by loessial soil. Due to serious soil and water erosion, a large area of sandstone is exposed. Because of its abundant coal resources, high altitude, inconvenient transportation, and ecological degradation, this zone is listed as a key area for coal mining and an ecological migration program (one kind of livelihood program conducted by the government aimed at relocating villages and households in an ecologically vulnerable area or an environmentally polluted area). Households are sparsely populated in this area.

The southeastern hilly-gully coal mining area includes the major parts of the townships of Xuejiawan and Longkou, with an area of $1203.88 \mathrm{~km}^{2}$, accounting for $15.65 \%$ of the whole county. This area is connected to the loess plateau of Shanxi and Shaanxi. The gully is deep and was developed quickly, with the land surface fragmented into tableland, girder land, replat land, and terrace land. This area also has abundant mineral resources and the largest coal open-pit mine in China.

The village of Changtan is in the loess hilly-gully region in the southeast of Jungar Banner, $40 \mathrm{~km}$ from the township of Xuejiawan. The village covers an area of $495.64 \mathrm{~km}^{2}$. It has more than 12 agricultural cooperatives and has a permanent population of 584 households with 953 people. The village is densely covered by gullies, and the soil types are mainly loessial and chestnut. It has $3.32 \mathrm{~km}^{2}$ of cultivated land, $1.43 \mathrm{~km}^{2}$ of forest, and $487.94 \mathrm{~km}^{2}$ of grassland (Figure 4). It has abundant coal resources, and there are two coal companies, Huineng Coal Mine and Yanggeleng Coal Mine, with a mining area of 3.38 hectares and annual coal production of 12 million tons. The Changchuan River used to flow through the village from north to south; however, due to coal exploitation, in recent years, both the surface and groundwater have dried up. Because of serious surface subsidence and dust pollution, most of the cultivated land and grassland can no longer be used for agricultural production.

\subsection{Livelihood Diversity among Four Villages}

\subsubsection{Livelihoods in Wujiayao Village}

As shown in Table 2 and Figure 3, rural households in the village of Wujiayao mainly earn their living by engaging in large-scale facility agriculture and specialized stockbreeding (see Figure 5). Planting-oriented and stockbreeding-oriented households account for $80.65 \%$ of total livelihoods, with the former dominating $(64.52 \%)$. A small number of households engage in nonfarm employment (half-labor and half-peasant households and nonagricultural-oriented households account for $12.90 \%$ and $6.45 \%$, respectively), while the percent of subsidized households is almost zero. Per-household net income is 55,800 yuan/year, and the livelihood diversity index is 1.77 , which are both the highest among the four typical villages. Farmers in this village possess the highest reported welfare and life satisfaction in Jungar Banner, with locally accessed water, clean energy, and good environmental sanitation.

Due to local advantages, including convenient location, flat terrain, bountiful land and water resources, and support from a scientific development strategy and management systems, rural livelihoods in Wujiayao have been successfully transformed from traditional to modernized and industrialized agriculture. Rural livelihoods couple well with the environment in this village to achieve a successful relationship. 
Table 2. Rural livelihoods and the environment in the four typical villages.

\begin{tabular}{|c|c|c|c|c|c|}
\hline \multicolumn{2}{|c|}{ Typical Village } & $\begin{array}{c}\text { Wujiayao } \\
\text { Village }\end{array}$ & $\begin{array}{c}\text { Gongyigai } \\
\text { Village }\end{array}$ & Fulu Village & $\begin{array}{c}\text { Changtan } \\
\text { Village }\end{array}$ \\
\hline \multicolumn{2}{|c|}{ Category of village } & $\begin{array}{c}\text { Modern } \\
\text { farm-pastoral } \\
\text { village and } \\
\text { pilot of new } \\
\text { rural } \\
\text { construction }\end{array}$ & $\begin{array}{c}\text { Traditional } \\
\text { farm-pastoral } \\
\text { village }\end{array}$ & $\begin{array}{l}\text { Suburban } \\
\text { transitional } \\
\text { village }\end{array}$ & $\begin{array}{l}\text { Coal resource } \\
\text {-dependent } \\
\text { village }\end{array}$ \\
\hline \multicolumn{2}{|c|}{ Geographical location } & $\begin{array}{l}\text { Alluvial plain } \\
\text { south of the } \\
\text { Yellow River } \\
\text { with flat terrain, } \\
\text { convenient } \\
\text { traffic, and } \\
\text { complete } \\
\text { infrastructure }\end{array}$ & $\begin{array}{l}\text { Traditional } \\
\text { farm-pastoral } \\
\text { zone of Kubuqi } \\
\text { Desert with a } \\
\text { few flat } \\
\text { lowlands } \\
\text { among sand } \\
\text { dunes }\end{array}$ & $\begin{array}{c}\text { Central } \\
\text { hilly-gully } \\
\text { sandstone and } \\
\text { urban } \\
\text { expansion zone, } \\
\text { suburban } \\
\text { location with } \\
\text { dense gullies }\end{array}$ & $\begin{array}{c}\text { Loess } \\
\text { hilly-gully } \\
\text { mining zone } \\
\text { with subsided } \\
\text { land and } \\
\text { fragmented } \\
\text { surfaces }\end{array}$ \\
\hline \multicolumn{2}{|c|}{ Resource endowment } & $\begin{array}{l}\text { Fertile soil, } \\
\text { sufficient water, } \\
\text { and flat and } \\
\text { concentrated } \\
\text { farmland with } \\
\text { complete water } \\
\text { infrastructure }\end{array}$ & $\begin{array}{l}\text { Mainly sparse } \\
\text { grassland and } \\
\text { forestland, a } \\
\text { few lowlands } \\
\text { with good soil } \\
\text { and water } \\
\text { conditions }\end{array}$ & $\begin{array}{c}\text { Scarce } \\
\text { cultivated land } \\
\text { of low quality; } \\
\text { two small } \\
\text { reservoirs but } \\
\text { with } \\
\text { insufficient } \\
\text { water }\end{array}$ & $\begin{array}{l}\text { Abundant coal } \\
\text { resources, } \\
\text { serious water } \\
\text { shortages, } \\
\text { scarce available } \\
\text { farmland and } \\
\text { forestland }\end{array}$ \\
\hline \multicolumn{2}{|c|}{ Environmental sanitation } & $\begin{array}{l}\text { Clean and tidy } \\
\text { environment, } \\
\text { well-regulated } \\
\text { houses, small } \\
\text { area of land } \\
\text { salinization }\end{array}$ & $\begin{array}{l}\text { Heavy drought } \\
\text { and serious soil } \\
\text { erosion from } \\
\text { wind and sand }\end{array}$ & $\begin{array}{l}\text { Serious soil } \\
\text { erosion by } \\
\text { humans, } \\
\text { scattered } \\
\text { houses, } \\
\text { garbage } \\
\text { pollution }\end{array}$ & $\begin{array}{c}\text { Serious air, } \\
\text { water, and soil } \\
\text { pollution from } \\
\text { coal dust }\end{array}$ \\
\hline \multicolumn{2}{|c|}{ Livelihood strategy } & $\begin{array}{l}\text { Dominated by } \\
\text { planting-oriented } \\
\text { livelihoods } \\
\text { consisting of } \\
\text { industrialized } \\
\text { agriculture }\end{array}$ & $\begin{array}{l}\text { Mainly } \\
\text { stockbreeding- } \\
\text { oriented, } \\
\text { nonagriculture-o } \\
\text { and subsidized } \\
\text { livelihoods }\end{array}$ & $\begin{array}{c}\text { Mainly } \\
\text { nonagriculture- } \\
\text { oriented and } \\
\text { iented } \\
\text { subsidized } \\
\text { livelihoods }\end{array}$ & $\begin{array}{c}\text { Dominated by } \\
\text { nonagriculture- } \\
\text { oriented } \\
\text { livelihoods } \\
\text { dependent on } \\
\text { coal digging }\end{array}$ \\
\hline \multirow{4}{*}{$\begin{array}{l}\text { Livelihood } \\
\text { outcome }\end{array}$} & $\begin{array}{l}\text { Family net } \\
\text { income }^{1} \\
\text { (104 yuan) }\end{array}$ & 5.58 & 5.44 & 3.68 & 4.24 \\
\hline & $\begin{array}{c}\text { Livelihood } \\
\text { diversity } \\
\text { index }{ }^{2}\end{array}$ & 1.77 & 1.67 & 1.54 & 1.47 \\
\hline & $\begin{array}{c}\text { Water } \\
\text { utilization }\end{array}$ & $\begin{array}{c}\text { Extracting } \\
\text { drinking water } \\
\text { from } 25 \mathrm{~m} \\
\text { underground } \\
\text { and production } \\
\text { water from the } \\
\text { Yellow River }\end{array}$ & $\begin{array}{c}\text { Extracting } \\
\text { drinking water } \\
\text { from } 60 \mathrm{~m} \\
\text { underground } \\
\text { and production } \\
\text { water from rain }\end{array}$ & $\begin{array}{l}\text { Drinking water } \\
\text { is from local } \\
\text { reservoir, and } \\
\text { production } \\
\text { water is from } \\
\text { rain }\end{array}$ & $\begin{array}{l}\text { Diverting water } \\
\text { from elsewhere }\end{array}$ \\
\hline & $\begin{array}{c}\text { Energy } \\
\text { utilization }\end{array}$ & $\begin{array}{l}\text { Electricity, } \\
\text { natural gas, } \\
\text { coal, solar } \\
\text { energy }\end{array}$ & $\begin{array}{l}\text { Coal, firewood, } \\
\text { electricity, } \\
\text { straw }\end{array}$ & $\begin{array}{l}\text { Coal, firewood, } \\
\text { electricity, } \\
\text { straw }\end{array}$ & $\begin{array}{l}\text { Coal and } \\
\text { electricity }\end{array}$ \\
\hline
\end{tabular}

${ }^{1}$ Kruskal-Wallis $\mathrm{H}=9.100, \mathrm{P}=0.028<0.05$, so we can reject the null hypothesis. 2 "Livelihood diversity index" is assigned a value of 1 for each livelihood vocation or activity undertaken by households. For example, if a household is engaged in farming and migrant jobs, the index of livelihood variety is 2 . Kruskal-Wallis $\mathrm{H}=11.483, \mathrm{P}=0.009<$ 0.05 , so we can reject the null hypothesis. 
"In 2003, our family migrated here and rented farmland from relatives to build this dairy farm with a 400 thousand yuan (RMB) investment. This farm covers 1.33 hectares and has 280 cows, 100 of which are owned by my family, and the rest are hosted for local villagers. In detail, the so-called hosted management is that local villagers bring their cows to the farm and provide forage by themselves, while we provide daily management and buy out their milk at a price of $3.2 \mathrm{yuan} / \mathrm{kg}$, slightly lower than the market $(3.7 \mathrm{yuan} / \mathrm{kg}$ ). Thus, we can bring about a 50,000 yuan (RMB) income for 60 households per year. Farmers sell surplus agricultural products (milk, corn, straw) to my farm to obtain cash income, and we provide them large amounts of manure." This cooperative farm-pastoral model can actually achieve cyclic, efficient, and clean production.

The running conditions of the dairy farm in normal years are roughly as follows:

\section{Annual income:}

Selling milk: $3.7 \mathrm{yuan} / \mathrm{kg} \times 20 \mathrm{~kg} / \mathrm{capita} /$ day $\times 280$ capita $\times 300$ days $=6,216,000$ yuan

Selling cows: 10 cows $\times 15,000$ yuan/cow $=150,000$ yuan

Selling manure: 100,000 yuan

Annual expenditure:

Purchase the milk from villagers: 3.2 yuan $/ \mathrm{kg} \times 20 \mathrm{~kg} / \mathrm{capita} /$ day $\times 180$ capita $\times 300$ days $=3,456,000$ yuan

Purchase concentrated fodder: 50,000 yuan/month $\times 12$ months $=600,000$ yuan

Purchase corn and straw: 800,000 yuan

Labor expenses: 3 people $\times 40,000$ yuan/person $=120,000$ yuan

Medical expenses: 30,000 yuan/year

Water and electricity fee: 5,000 yuan/year

Annual net income: 1,450,000 yuan

- According to an interview with Mr. Chen, the owner of a dairy farm in Wujiayao (30 December 2015; N40¹6'05", E11044'42")

Figure 5. Interview with a farmer in Wujiayao village.

\subsubsection{Livelihoods in Gongyigai Village.}

Due to environmental constraints, farmers in the village of Gongyigai still adhere to the traditional production mode of animal husbandry combined with extensive crop cultivation for animal feeding. Hence, most of them choose stockbreeding-oriented livelihoods (30\%) and planting-oriented livelihoods $(6.67 \%)$. Under the impact of urbanization and industrialization, some have moved to nonagricultural-oriented livelihoods $(26.67 \%)$ and half-labor and half-peasant livelihoods $(10 \%)$. The rest are subsidized farmers, accounting for $26.67 \%$. The per-household net income of the village is about 54,400 yuan/year, and the livelihood diversity index is 1.67 . The values of these two indicators are second only to those of the village of Wujia.

The livelihoods of rural households in Gongyigai are compatible with the environment, with a stable and balanced state maintained. However, the environment of this village is extremely fragile, with high wind-induced erosion and limited capacity in terms of both resources and the environment. Because of this fragility, it is important to control the intensity of exploitation of environmental resources to maintain the sustainability of farmers' livelihoods.

\subsubsection{Livelihoods in Fulu Village}

Due to the advantages of its suburban location, the village of Fulu is encouraged by local governments to develop fruit cultivation, vegetable greenhouse construction, agro-tourism, and peasant-household tourism. Nevertheless, due to water shortages, densely populated valleys, and policy hysteresis, the transformation away from rural livelihoods in Fulu is not obvious. Farmers are mainly engaged in nonagricultural activities such as businesses, auxiliary craftsmanship, and migrant jobs. Young adults mostly earn their living in urban areas, leaving the elderly and children behind. 
Nonagricultural-oriented and subsidized households account for $36.36 \%$ and $34.09 \%$, respectively, in this village (Figure 3), while $18.18 \%$ of households are engaged in a stockbreeding-oriented livelihood. According to the survey data, the average household net income is about 36,800 yuan/year, which was the lowest among the four villages. The means to live are relatively limited, with a livelihood diversity index of 1.54 and a medium reported welfare level. The drinking water comes from reservoirs, while agricultural water is in short supply. The energy used for production and living is dominated by coal and electricity.

The main dilemmas in Fulu are water shortages, limitations caused by the topography, undeveloped agricultural techniques, and inadequate management (see Figure 6). Faced with these disadvantages, the inherent relationship between rural livelihoods and the environment has reached a saturation state. One effective way used to improve a household's livelihood is to migrate to the nearest urban area for nonfarm employment, and advanced production technologies should be introduced to local industries. Relevant vocational training is necessary for farmers to improve their farming technology and management and learn new nonfarming job skills.

"In 2009, our village collectively leased 17.8 hectares of grassland to the Jiahe Agricultural Development Company at a price of 4200 yuan/hectare/year. The contract was signed for 18 years, involving more than 80 households and 240 farmers. The per capita income will increase by 300 yuan. The company mainly produces fresh fruits and vegetables to supply the town of Shagedu (nearby, urban). The company has full authority for management, employing about 10 rural laborers and possessing more than 60 greenhouses. The annual production value is about 2 million RMB." However, this "company + base" model, due to poor management, low production efficiency, and a lack of farmer participation, does not efficiently promote employment. In addition to high costs and market fluctuations, this model is not sustainable.

- According to an interview with Mr. $\mathrm{Xu}$, the head of the village of Fulu (22 December $\left.2015 ; \mathrm{N} 39^{\circ} 36^{\prime} 52^{\prime \prime}, \mathrm{E} 110^{\circ} 54^{\prime} 39^{\prime \prime}\right)$

Figure 6. Interview with the head of Fulu village.

\subsubsection{Livelihoods in Changtan Village}

In the past, the Changchuan River stretched about $5 \mathrm{~km}$ through the village and had abundant water resources and fertile lands. Planting, husbandry, forestry, and the fruit industry covered a long beach along the river. Local households mainly engaged in agriculture and handicrafts as their main livelihoods. In recent years, coal mining and land expropriation have made farmers become rich quickly. Nevertheless, due to unreasonable squandering, farmers have now become poor once more. Serious damage caused by coal mining has caused land subsidence, soil erosion, and dust pollution and has forced a large number of villagers to migrate, leaving the elderly behind. The remaining households mainly earn their living by working in the coal mines. As shown in Table 2 and Figure 3, nonagricultural-oriented households who make a living in cities and coal mining account for $66.67 \%$ of the total, and subsidized households account for $26.98 \%$. The average household net income is 42,400 yuan/year, third among the four villages. The livelihood diversity index is 1.47 , which is the lowest. The living conditions in this village are the worst due to serious pollution and water shortages. Water for household life is diverted from other places, while water for agricultural production depends entirely on rainfall. The dominant energy is coal, which in turn aggravates pollution.

The village of Changtan is a typical case of rural recession and resource exhaustion in the process of urbanization and industrialization in China. The main reason for this is due to an unreasonable exploitation of resources in conjunction with encroachment upon farmers' property rights (such as the compulsory buyout of coal mining rights and land ownership). Correspondingly, effective countermeasures include changing the way resources are utilized, adopting clean production measures, 
and empowering rural households with property rights, environmental supervision rights, and public affairs participation rights. The transformation should be conducted by the government and be participated in by households.

\subsection{Livelihood-Environment Nexus}

In this case study, the environment can be seen as a complex system composed of two parts: the natural environment and the human environment. The natural environment consists of various natural elements such as climate, topography, landforms, soil, water, and mineral resources. The natural world has always been utilized as a means of production and labor to facilitate human survival. The human environment (also called the social environment), which is always related to the economy, politics, culture, history, transportation, and distance from cities and towns, is essential for social development. At the community level, the choice of livelihood is made within a specific village space and has different principal modes according to the characteristics of natural and human factors. The village-level environment is the most direct and closest external environment that affects the livelihood of rural households. A combination of geographical location, resource endowment, and environmental sanitation affects rural livelihoods in terms of spatial patterns, development capacity, and quality of life within the context of the public ownership system, the utilization policy of land resources, and limited technical conditions. Meanwhile, the village-level environment is also reshaped by the livelihood activities of rural households (see Figure 7). Rural development activities, together with farmers' livelihood activities in terms of the use of natural resources (arable land, mineral resources, etc.), have changed land use patterns, resulting in either favorable (afforest) or detrimental environmental influences (soil erosion, environmental pollution, landscape fragmentation, etc.).

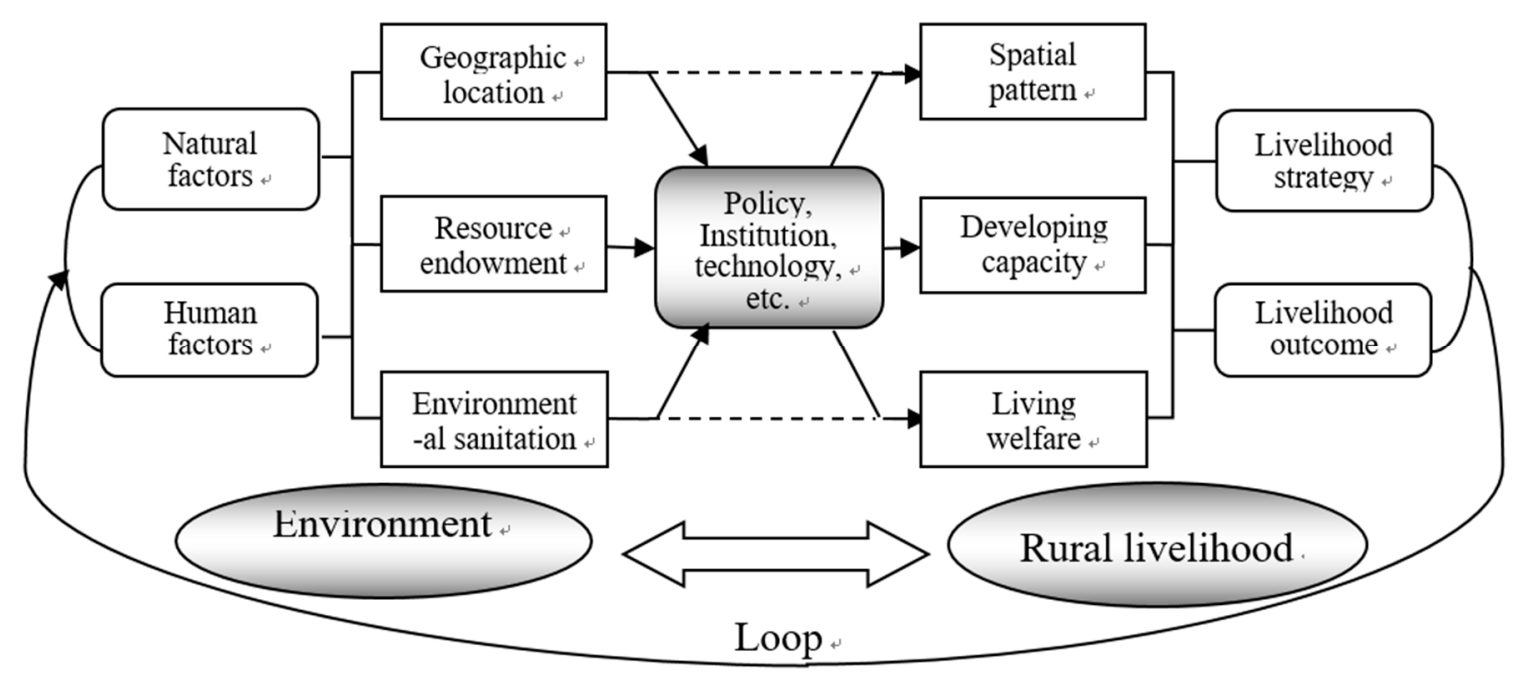

Figure 7. Livelihood-environment coupling mechanism at a village scale.

In terms of geographical location, natural and economic characteristics associated with landform, elevation, traffic conditions, and distances to public service facilities (such as markets and hospitals) severely influence a rural household's decision-making, especially with respect to a choice of a nonagricultural livelihood. Farmers in the village of Fulu tend to migrate to nearby urban areas for nonfarming livelihoods because of its suburban location, while farmers in the village of Wujiayao are willing to adopt modern-facility agriculture due to flat regional landforms and concentrated farmland. In these cases, the presence and distribution of natural resources such as land, water, and minerals determine the potential development capacity of rural livelihoods. Fertile farmland resources in Wujiayao and abundant coal resources in the village of Changtan provide a better development foundation and higher capacity than in other villages. However, different types of resources cause livelihoods to develop in different directions in these two villages, and their specific management 
systems contribute to either good or bad livelihood outcomes. The impact of environmental sanitation is mainly reflected in household welfare in terms of rural industrial pollution, agricultural pollution, and garbage pollution. Long-term sand erosion in the village of Gongyigai and dust pollution caused by coal mining in the village of Changtan have seriously affected local residents' livelihoods and quality of life and have forced some farmers to relocate.

Rural households select an applicable livelihood strategy according to the specific environment of their village. Livelihood modes in the same village are generally the same, while different villages exert livelihood diversity and spatial regularity due to environmental heterogeneity. It is the spatial heterogeneity of the environment that determines the spatial diversity of rural livelihoods at the village level.

Rural livelihoods couple with the village-level environment in various ways. Coupling mechanisms include (i) homeostatic type: generally, in most villages, rural livelihoods are basically compatible with the capacity of the environment. The resource and environmental carrying capacity and the livelihoods of rural households are maintained in a balanced state and will not dramatically change in a short period of time (Figure 8A). For instance, households in the village of Gongyigai have long engaged in traditional stockbreeding-oriented livelihoods, which is unique to the agricultural-pastoral zone due to its relatively isolated location and limited environmental capacity. (ii) Intense type: in resource-abundant villages, intensive resource extraction can bring high revenues to local residents, so they tend to adopt a resource-dependent livelihood. However, if resources are overexploited and the environment is not protected, a "resource curse" will occur, with degraded ecosystems, exhausted resources, and high levels of a return to poverty (Figure 8B). The failure to successfully transition between livelihoods in the village of Changtan has been a direct result of excessive exploitation of coal resources and the destruction of the local environment, in addition to a lack of property rights and ill-suited management systems. (iii) Transfer type: In some villages, despite limited environmental capacity, rural livelihoods progress due to population outflows or resource inflows (Figure 8C). These villages tend to be close to urban centers and have the advantage of facilitated transport. The nonagricultural livelihood transition of rural households in the village of Fulu is a typical case of this. (iv) Optimized type: Only a few villages have simultaneously attained mutual promotion in both the environment and rural livelihoods due to the introduction of technologies or institutional innovation (Figure 8D). In the village of Wujiayao, for example, the livelihood-environment relationship is in an ideally coupled state due to good farmland resources and management system reform. 

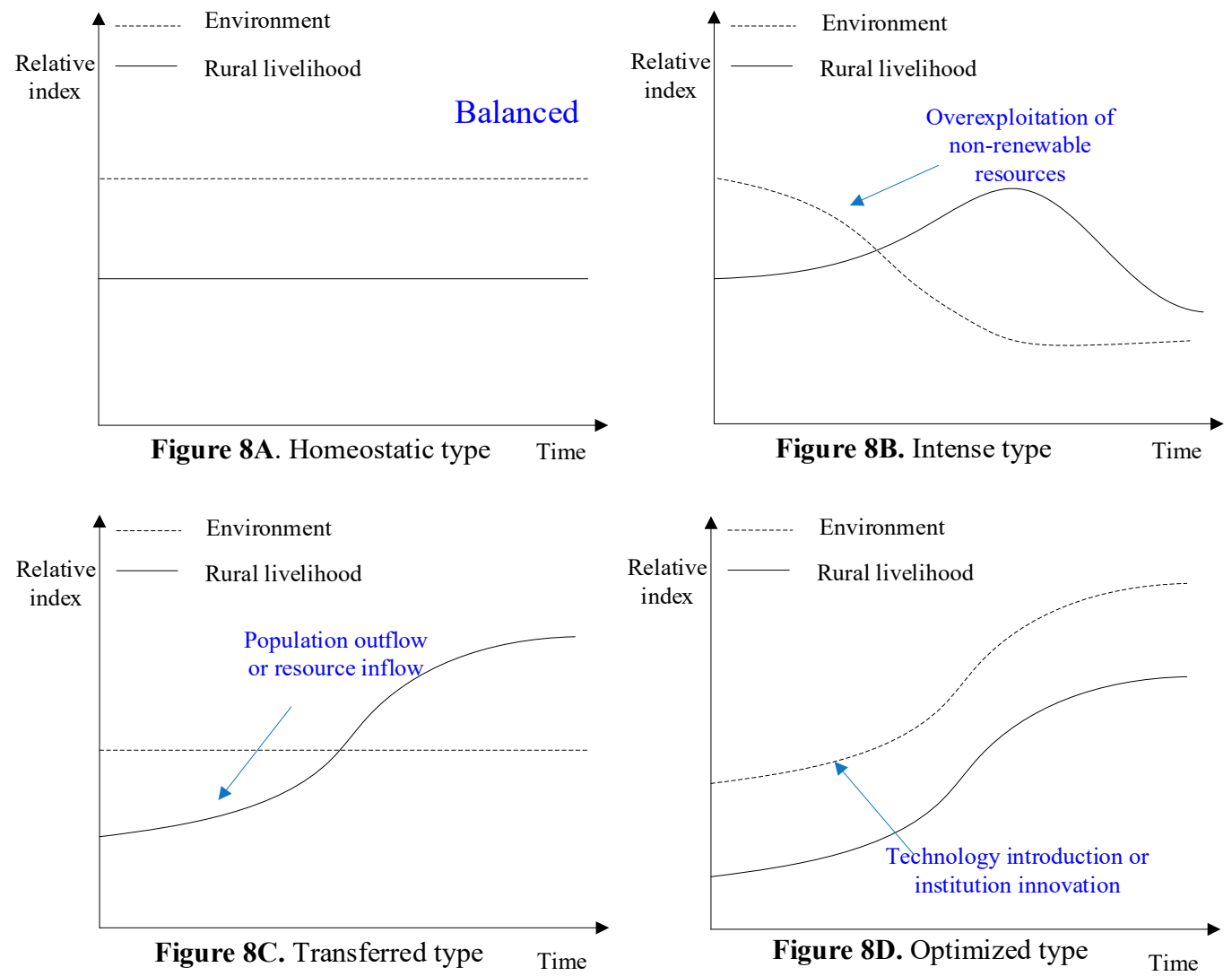

Figure 8. Coupling relationship between rural livelihoods and the environment.

\section{Discussion}

Rural recession, which is characterized by population decline [50,51], environmental degradation [52,53], farmland abandonment [54], and concentrated poverty [24,55], has become a global trend. Livelihood-environment nexus research may provide a useful perspective for countryside revitalization.

The case study of Jungar Banner indicates that although these areas are becoming more urbanized and industrialized, the rural livelihood and environmental relationship will not develop spontaneously toward a virtuous status without policy intervention. Due to there being various environmental factors, countryside revitalization must be locally tailored and implemented according to the specific conditions in a given rural livelihood-environment nexus on a village scale. Government reform should address institutions of both rural utilization and management and should make efforts to change the geographical situation, increase resource accessibility, and improve environmental sanitation.

Specifically, in resource-abundant villages, resource utilization policies and institutional management are crucial [56,57]. Under the current system of public ownership in China, farmers' resource property rights are not guaranteed, which has actually undermined rural livelihoods during recent decades [52,53]. In the village of Changtan, the compulsory buyout of mineral rights and a one-time compensation are not conducive to the establishment of sustainable livelihoods for local households. In contrast, farmers' livelihoods in the village of Wujiayao are more successful due to their partial possession of farmland rights and their positive participation in management with a local agricultural company. According to the empowerment theory, the basis/precondition for sustainable rural development is the empowerment of external rights, including resource ownership, management rights, and participation rights in community decision-making [58]. Therefore, rural revitalization in a resource-abundant village should put particular emphasis on the revitalization of the rights of rural households. In peri-urban villages with advantageous geographical locations, such as Fulu, moving to an urban area and nonfarm employment are wise and lucrative livelihood choices [59,60]. However, 
this demands relatively high-quality human capital [61-63]. Hence, rural revitalization in a peri-urban village depends much more on the labor revitalization of rural households through education and training in new skills by the government.

In remote, barren villages or polluted villages, such as Changtan, land overexploitation and environmental degradation tends to occur, and ecological migration and environmental restoration are preferable strategies. Rural revitalization in these villages should focus on environmental revitalization. Villages such as Gongyigai have limited resources and environmental carrying capabilities, and rural livelihood development is stagnant. It is hard for the community to break through entirely on their own under solidified economic circumstances [64]. As indicated by documents issued by the State Council of China, prosperous rural industry is the focus in these areas [65] (both a reason for and a result of rural endogenous development) [66]. In these villages, in addition to empowering farmers with both external rights and inner capability, rural industrial revitalization can be reached through a recombination of resources, organizations, culture, and related infrastructure construction.

The relationship between rural livelihoods and the environment is complex and geographically dependent. Therefore, from the perspective of the rural livelihood-environment relationship, rural revitalization should focus on four aspects: "rights revitalization", "labor revitalization", "industrial revitalization", and "environmental revitalization". The goal of rural revitalization should include coordinating and optimizing the coupled rural livelihood-environment relationship.

\section{Conclusions}

This study provides an example of how rural livelihoods couple with a fragile environment in a farm-pastoral county in the Loess Plateau. Through qualitative and quantitative methods from social, environmental, and geographical sciences, this study conducted a geographical regionalization and a comparative analysis of four typical villages. The results indicated that rural livelihoods tightly couple with the environment on a village scale, showing significant geographical regularity and spatial disparity. In summary, livelihood strategies adopted by rural households are generally adaptive to the environment. Meanwhile, livelihood outcomes, such as family net income and a livelihood diversity index, showed significant disparities between the different zones. Farmers living in the alluvial plain to the south of the Yellow River mainly adopt modernized plantation and cooperative stockbreeding due to their advantageous soil and water. Family net income (55.8 thousand yuan) and the livelihood diversity index (1.77) in this region are the highest compared to the other regions. Livelihoods in the Kubuqi Desert area comprise traditional stockbreeding, migrant work, and subsidized livelihoods because of limited resources and environmental capacity. Farmers in this region have the second highest family net income (54.4 thousand yuan) and livelihood diversity index (1.67). Households in the peri-urban village of the central sandstone hilly-gully area, which has the lowest net income (36.8 thousand yuan) and a medium diversity index (1.54), tend to migrate to urban cities to pursue livelihoods. Finally, livelihoods in the mining village of the southern loess hilly-gully area are dominated by nonagricultural work associated with coal mining, but there is a low quality of life due to a polluted environment. Family net income and the livelihood diversity index are 4.24 thousand yuan and 1.47, respectively, in this region.

The village-level environment is closely related to farmers. Its spatial heterogeneity determines the spatial diversity of rural livelihoods. A combination of geographical location, resource endowment, and environmental sanitation jointly affect rural livelihoods in terms of their spatial patterns, development capacity, and living welfare in the context of the public ownership system, the utilization policy of land resources, and limited technical conditions. At the same time, the village-level environment has also suffered adverse effects from farmers' livelihoods. According to this empirical study in four typical villages, the coupled relationship between rural livelihoods and the environment can be summarized as "homeostatic", "intense", "transferred", and "optimized".

Various coupled relationships between the human and environmental systems in Jungar Banner indicate that despite high urbanization and industrialization, the conflict between rural livelihood 
development and environmental protection still exists and will not be resolved without policy intervention. Therefore, countryside revitalization must be locally tailored on a village scale and implemented according to specific conditions of the rural livelihood-environment nexus. Specifically, in resource-abundant villages such as Changtan and Wujiayao, rural revitalization should put particular emphasis on rights revitalization among rural households through policy and institutional reform. In peri-urban villages with advantageous geographical locations, such as Fulu, rural revitalization depends much more on the labor revitalization of rural households through education and skills training. In remote, barren villages or polluted villages such as Changtan, rural revitalization should focus on environmental revitalization. Finally, in villages such as Gongyigai, where rural livelihoods and environmental development are stagnant, rural industrial revitalization should be the focus through a recombination of productive elements and technological innovation.

This study contributes to the current literature on coupled human-environment systems and narrows the research gap, as few studies have systematically analyzed the rural livelihood-environment nexus on a village scale by combining the sciences of geography and sociology. This study may provide references for China's countryside revitalization and global human-environment relationship management.

Author Contributions: Conceptualization, Z.W. and B.L.; methodology, Z.W.; software, X.D.; investigation, Z.W. and X.D.; data curation, X.D.; formal analysis, Y.H.; writing-original draft preparation, Z.W.; writing-review and editing, Y.H.; funding acquisition, Z.W. and B.L. All authors have read and agreed to the published version of the manuscript.

Funding: This research was funded by the National Natural Science Foundation of China (No. 40871135, No. 41861036); the Specialized Research Fund for the Doctoral Program of Higher Education Project (No. 20120003110017); the 63rd Batch of the China Postdoctoral Science Foundation Fund (No.2018M630738); the Humanities and Social Sciences Research Project of Jiangxi University (No.GL18238); the Young Doctor Fund of the Jiangxi Social Science Plan (No.17BJ38); and the Jiangxi Natural Science Foundation (20192BAB213023).

Acknowledgments: The authors would like to thank all of the participant farmers in the household survey for their collaboration in this study. We acknowledge the contribution of experts from the Institute of Geographic Sciences and Natural Resources Research, CAS, China Agricultural University, Beijing Normal University, and the local government for their support and advice on the geographical regionalization. We are grateful to CAS and the Jungar Department of Natural Resources for contributing to the spatial data and GIS map.

Conflicts of Interest: The authors declare no conflicts of interest.

\section{References}

1. Cai, Y.L. Study patterns of human-land relationship: Philosophical and ethical speculation. Hum. Geogr. 1996, 1, 1-6. (In Chinese).

2. Regen, T. Earthbounk: New Introduction Essays in Environmental Ethics; Random House: Chicago, IL, USA, 1984; pp. 270-274.

3. Liu, J.; Dietz, T.; Carpenter, S.R.; Alberti, M.; Folke, C.; Moran, E.; Pell, N.A.; Deadman, P.; Kratz, T.; Lubchenco, J.; et al. Complexity of coupled human and natural systems. Science 2007, 317, 1513-1516. [CrossRef] [PubMed]

4. Turner, B.L.; Clark, W.; Kates, R.; Richards, J.; Mathews, J.; Meyer, W. The Earth as Transformed by Human Action: Global and Regional Changes in the Biosphere over the Past 300 Years; Cambridge University Press: Cambridge, UK, 1990; pp. 45-50.

5. Forman, R.T.T. Land Mosaics: The Ecology of Landscapes and Regions; Cambridge University Press: Cambridge, UK, 1995; p. 656.

6. Vitousek, P.M.; Mooney, H.A.; Lubchenco, J.; Melillo, J.M. Human domination of earth's ecosystems. Science 1997, 277, 494-499. [CrossRef]

7. Gunderson, L.H.; Holling, C.S. Panarchy: Understanding Transformation in Human and Natural Systems; Island Press, Washington, DC, USA, 2001; pp. 60-68.

8. Berkes, F.; Folke, C. Linking Social and Ecological Systems: Management Practices and Social Mechanisms for Building Resilience; Cambridge University Press: Cambridge, UK, 1998; pp. 41-49. 
9. Ingegnoli, V. Landscape Bionomics, Biological-Integrated Landscape Ecology; Springer Verlag: Milan, Italy, 2015; p. 431.

10. Wu, J. Landscape Ecology: Pattern, Process, Scale and Hierarchy, 2nd ed.; Higher Education Press: Beijing, China, 2007; p. 266. (In Chinese)

11. Hull, V.; Moran, E.; Nagendra, H.; Swaffield, S.R. Applications of the Telecoupling Framework to Land-Change Science. Rethink. Glob. Land Use Urban Era 2014, 1, 19-39.

12. Friis, C. Telecoupling: A New Framework for Researching Land-Use Change in a Globalised World. In Telecoupling; Friis, C., Nielsen, J., Eds.; Springer Palgrave Macmillan: Cham, Switzerland, 2019; pp. 49-67.

13. DFID. Sustainable Livelihoods Guidance Sheets. Department for International Development: London, UK, 2000. Available online: http://agris.fao.org/agris-search/search.do?recordID=XF2015036535 (accessed on 17 October 2017).

14. Ellis, F. Rural Livelihood Diversity in Developing Countries: Evidence and Policy Implications; Oxford University Press: Oxford, UK, 2000; pp. 248-252.

15. Chen, H.; Zhu, T.; Krott, M.; Calvo, J.F.; Ganesh, S.P.; Makoto, I. Measurement and evaluation of livelihood assets in sustainable forest commons governance. Land Use Policy 2013, 30, 908-914. [CrossRef]

16. Labao, A.B.; Naval, P.C.; Yap, D.L.T.; Yap, H.T. Influencing rural livelihood switching through equipment assets for agroecosystems to alleviate pressure on resources. Agric. Ecosyst. Environ. 2018, 248, 96-104. [CrossRef]

17. Barrett, C.B.; Bezuneh, M.; Aboud, A. Income diversification, poverty traps and policy shocks in co^te d'Ivoire and Kenya. Food Policy 2001, 26, 367-384. [CrossRef]

18. Fang, Y.P.; Fan, J.; Shen, M.Y.; Song, M.Q. Sensitivity of livelihood strategy to livelihood capital in mountain areas: Empirical analysis based on different settlements in the upper reaches of the Minjiang River, China. Ecol. Indic. 2014, 38, 225-235. [CrossRef]

19. Sun, G.Y.; Wang, C.S.; Xiao, L.; Liu, Y. Spatial change and its influence factors of rural settlements in Xiji of Ningxia in Loess Plateau area. J. Univ. Chin. Acad. Sci. 2015, 32, 612-619. (In Chinese).

20. Kariuki, R.; Willcock, S.; Marchant, R. Rangeland Livelihood Strategies under Varying Climate Regimes: Model Insights from Southern Kenya. Land 2018, 7, 47. [CrossRef]

21. Barrett, C.B.; Reardon, T.; Webb, P. Nonfarm income diversification and household livelihood strategies in rural Africa: Concepts, dynamics, and policy implications. Food Policy 2001, 26, 315-331. [CrossRef]

22. Duguma, L.A. Financial analysis of agroforestry land uses and its implications for smallholder farmers livelihood improvement in Ethiopia. Agrofor. Syst. 2013, 87, 217-231. [CrossRef]

23. Li, S.C.; Xu, Y.Q.; Fu, X.F. Spatial Simulation Using GIS and ANN for Regional Pauperization in China. Resour. Sci. 2005, 27, 76-81. (In Chinese).

24. Liu, Y.S.; Liu, J.L.; Zhou, Y. Spatio-temporal patterns of rural poverty in China and targeted poverty alleviation strategies. J. Rural. Stud. 2017, 52, 66-75. [CrossRef]

25. Ward, C.D.; Shackleton, C.M. Natural resource use, incomes, and poverty along the rural-urban continuum of two medium-sized, South African towns. World Dev. 2016, 78, 80-93. [CrossRef]

26. Cao, H.M. Support union: An important institution innovation in rural poverty alleviation-A pilot case study of "Doing well in poverty alleviation and development, and building a harmonious socialist society" in Yilong County, Sichuan province. Chin. Rural. Econ. 2007, 9, 72-76. (In Chinese).

27. Mcintyre, N.; Bulovic, N.; Cane, I.; Mckenna, P. A multi-disciplinary approach to understanding the impacts of mines on traditional uses of water in northern Mongolia. Sci. Total. Environ. 2016, 557-558, 404-414. [CrossRef]

28. Su, R.; Cheng, J.; Chen, D.; Bai, Y.; Hua, J.; Chao, L.; Wang, Z.; Li, J. Effects of grazing on spatiotemporal variations in community structure and ecosystem function on the grasslands of Inner Mongolia, China. Sci. Rep. 2017, 7, 40. [CrossRef] [PubMed]

29. Montgomery, S.C.; Martin, R.J.; Guppy, C.; Wright, G.C.; Tighe, M.K. Farmer knowledge and perception of production constraints in northwest Cambodia. J. Rural. Stud. 2017, 56, 12-20. [CrossRef]

30. Qu, W.; Tu, Q.; Niu, S.W. Examining the poverty effects of natural geographical environment: An empirical analysis on the effects of natural geography on rural poverty. Chin. Rural. Econ. 2012, 2, 21-34. (In Chinese).

31. Huang, G.Y.; Zhang, M.; Xia, Y. Poor effect test of natural geographical environment in arid areas: Quantile regression method based on panel data. Arid. Land Geogr. 2015, 38, 814-820. (In Chinese). 
32. Dao, T.N.; Edenhofer, O. On the Fiscal Strategies Of Escaping Poverty-Environment Traps (and) towards Sustainable Growth; Cesifo Working Paper; EconStor: Hamburg, Germany, 2014; p. 55. [CrossRef]

33. Arunachalam, R.; Shenoy, A. Poverty traps, convergence, and the dynamics of household income. J. Dev. Econ. 2017, 126, 215-230. [CrossRef]

34. Amarasinghe, U.; Samad, M.; Anputhas, M. Spatial clustering of rural poverty and food insecurity in Sri Lanka. Food Policy 2005, 30, 493-509. [CrossRef]

35. Liu, X.P.; Su, X.F.; Wang, Y.J.; Zhao, Y.; Huang, Y. Review on spatial poverty and deprivation and its enlightenments to poverty geography studies in China. Arid Land Geogr. 2014, 37, 144-152.

36. Zheng, H.; Robinson, B.E.; Liang, Y.C.; Polasky, S.; Ma, D.C.; Wang, F.C.; Ruckelshaus, M.; Ouyang, Z.Y.; Daily, G.C. Benefits, costs, and livelihood implications of a regional payment for ecosystem service program. PNAS 2013, 110, 16681-16686. [CrossRef]

37. Li, C.; Zheng, H.; Li, S.; Chen, X.; Li, J.; Zeng, W.; Liang, Y.; Polasky, S.; Feldman, W.M.; Ruckelshaus, M.; et al. Impacts of conservation and human development policy across stakeholders and scales. PNAS 2015, 112, 7396-7401. [CrossRef]

38. Lei, Y.; Zhang, H.; Chen, F.; Zhang, L. How rural land use management facilitates drought risk adaptation in a changing climate-A case study in arid northern china. Sci. Total. Environ. 2016, 550, 192. [CrossRef]

39. Li, Y.R.; Liu, Y.S.; Long, H.L.; Guo, Y.J. Village transformation development, resources and environment effects and their optimal regulation in the metropolitan suburbs: The case of Beicun in Shunyi District, Beijing. Acta Geogr. Sin. 2013, 68, 825-838. (In Chinese).

40. Tu, S.; Long, H.; Zhang, Y.; Ge, D.; Qu, Y. Rural restructuring at village level under rapid urbanization in metropolitan suburbs of China and its implications for innovations in land use policy. Habitat Int. 2018, 77, 143-152. [CrossRef]

41. Cheng, X. Frontier issue of modern ecology in the study of ecotone between agriculture and animal husbandry. Resour. Sci. 1999, 21,1-9. (In Chinese).

42. Zhao, H.L.; Zhao, X.Y.; Zhang, T.H. Boundary line on agro-pasture zigzag zone in north China and its problems on eco-environment. Adv. Earth Sci. 2002, 5, 739-748. (In Chinese).

43. Ren, J.Z.; He, D.H.; Wang, N.; Zhu, X.Y.; Li, Z.Q. Models of coupling ago-grassland system in desert-oasis region. Acta Prataculturae Sin. 1995, 4, 11-19. (In Chinese).

44. Han, J.G.; Sun, Q.Z.; Ma, C.H. Sustainable Develop Technology for Farming and Animal Husbandry in the Agro-Pasturage Ecotone, 1st ed.; Chemical Industry Press: Beijing, China, 2004. (In Chinese)

45. Liu, H.L.; Wang, Y.M.; Dou, X.; Xu, M.Y.; Wang, K. Progress and perspective of agro-pasturage ecotone. Acta Ecol. Sinica 2009, 29, 4420-4425. (In Chinese).

46. Wu, Z.L.; Li, B.; Hou, Y. Adaptive choice of livelihood patterns in rural households in a farm-pastoral zone: A case study in Jungar, Inner Mongolia. Land Use Policy 2017, 62, 361-375. [CrossRef]

47. Jungar Statistical Bureau. The Statistical Yearbook of Jungar Banner (2018); Inner Mongolia People's Publishing House: Hohhot, China, 2018.

48. Zhao, J.; Barry, P. Implications of different income diversification indexes. In The Case of Rural China. Economics and Business Letters; Oviedo University Press: Oviedo, Spain, 2013; Volume 2, pp. 13-20. [CrossRef]

49. Liu, Z.; Lan, J. The sloping land conversion program in China: Effect on the livelihood diversification of rural households. World Dev. 2015, 70, 147-161. [CrossRef]

50. Liu, Y.S.; Li, Y.H. Revitalize the world's countryside. Nature 2017, 548, 275-277. [CrossRef]

51. Liu, J. Ageing, migration and familial support in rural China. Geoforum 2014, 51, 305-312. [CrossRef]

52. Lu, J.; Lora-Wainwright, A. Historicizing Sustainable Livelihoods: A Pathways Approach to Lead Mining in Rural Central China. World Dev. 2014, 62, 189-200. [CrossRef]

53. Dong, X.; Dai, G.; Ulgiati, S.; Na, R.; Zhang, X.; Kang, M.; Wang, X. On the relationship between economic development, environmental integrity and well-being: The point of view of herdsmen in northern china grassland. PLoS ONE 2015, 10, e0134786. [CrossRef] [PubMed]

54. Long, H.L.; Zou, J.; Pykett, J.; Li, Y.R. Analysis of rural transformation development in China since the turn of the new millennium. Appl. Geogr. 2011, 31, 1094-1105. [CrossRef]

55. Hilson, G. 'Once a miner, always a miner': Poverty and livelihood diversification in Akwatia, Ghana. J. Rural. Stud. 2010, 26, 296-307. [CrossRef] 
56. Palacios, M.R.; Huber-Sannwald, E.; Barrios, L.G.; De-Paz, F.P.; Hernandez, J.C.; Mendoza, M.D.G. Landscape diversity in a rural territory: Emerging land use mosaics coupled to livelihood diversification. Land Use Policy 2013, 30, 814-824. [CrossRef]

57. Hak, S.; McAndrew, J.; Neef, A. Impact of Government Policies and Corporate Land Grabs on Indigenous People's Access to Common Lands and Livelihood Resilience in Northeast Cambodia. Land 2018, 7, 122. [CrossRef]

58. Zimmerman, M.A. Taking aim on empowerment research: On the distinction between individual and psychological conceptions. Am. J. Community Psychol. 1990, 18, 169-177. [CrossRef]

59. Cobbinah, P.B.; Gaisie, E.; Owusu-Amponsah, L. Peri-urban morphology and indigenous livelihoods in Ghana. Habitat Int. 2015, 50, 120-129. [CrossRef]

60. Liu, Z.X.; Liu, L.M. Characteristics and driving factors of rural livelihood transition in the east coastal region of China: A case study of suburban Shanghai. J. Rural. Stud. 2016, 43, 145-158. [CrossRef]

61. Hu, F.; Xu, Z.Y.; Chen, Y.Y. Circular migration, or permanent stay? Evidence from China's rural-urban migration. China Econ. Rev. 2011, 22, 64-74. [CrossRef]

62. Bhandari, P.B. Rural livelihood change? Household capital, community resources and livelihood transition. J. Rural. Stud. 2013, 32, 126-136. [CrossRef]

63. Huang, X.J.; Huang, X.; He, Y.B.; Yang, X.J. Assessment of livelihood vulnerability of land-lost farmers in urban fringes: A case study of Xi'an. China. Habitat Int. 2017, 59, 1-9. [CrossRef]

64. Wang, C.C. The Ecological Effect of Farmer Household Livelihood Transition-A Case Study on the Basis of Community Empowerment Theory. Chin. Agric. Sci. Bull. 2010, 26, 315-319. (In Chinese).

65. Song, Y. Advices on the Implementation of Rural Revitalization Strategy by the CPC Central Committee. Xinhua News Agency. Available online: http://www.gov.cn/zhengce/2018-02/04/content_5263807.htm (accessed on 4 February 2018).

66. Dong, J.Z. Reflections on the implementation of the Countryside Revitalization Strategy. Rural. Work. Commun. 2017, 22, 15-18. (In Chinese).

(C) 2020 by the authors. Licensee MDPI, Basel, Switzerland. This article is an open access article distributed under the terms and conditions of the Creative Commons Attribution (CC BY) license (http://creativecommons.org/licenses/by/4.0/). 